\title{
Determinan Konsistensi Penggunaan Kondom pada Laki-Laki Seks dengan Laki-Laki (LSL) Non-Pekerja Seks: Studi Potong Lintang
}

\section{Determinants of Consistency of Condom Use on Men Who Have Sex with Man (MSM) Nonsexual Workers: Cross Sectional Study}

\author{
Arum Zulaikhah*, Sudarto Ronoatmodjo \\ ${ }^{a *}$ BPJS Kesehatan KC Kebumen, Jln. Sarbini No. 100, Bumirejo, Kec. Kebumen, Indonesia \\ ${ }^{\mathrm{b}}$ Departemen Epidemiologi, Fakultas Kesehatan Masyarakat Universitas Indonesia, Lantai 1 Gedung A, Kampus UI Depok, Indonesia
}

A B S T R A K

Kasus baru HIV di Indonesia cenderung terus mengalami peningkatan. Sedangkan, tren kasus baru di dunia sudah mengalami penurunan. Laki-laki Seks dengan laki-laki (LSL) merupakan kelompok risiko tinggi HIV. Upaya pencegahan penularan HIV erat kaitannya dengan perilaku seks. Studi ini menggunakan 1.161 sampel Survei Terpadu Biologi dan Perilaku (STBP) 2015 pada kelompok LSL yang termasuk bukan pekerja seks. Studi cross sectional ini bertujuan untuk menganalisis determinan perilaku seks konsistensi penggunaan kondom dengan analisis hingga bivariat dengan menggunakan chi-square dan prevalence ratio. Data didapatkan dengan metode respondent driven sampling (RDS) yang kemudian mengeksklusi LSL pekerja seks. Hasil menunjukkan bahwa faktor-faktor yang berhubungan dengan perilaku penggunaan kondom yang tidak konsisten yaitu pengetahuan status HIV dengan prevalence ratio (PR) 1,14 (95\% CI 1,02-1,28), pelayanan pencegahan dan penularan HIV dengan PR 1,18 (95\% CI 1,06-1,33), serta akses terhadap internet tentang pencegahan dan penularan HIV dengan $P R$ 1,16 (95\% CI 1,02-1,31). Sehingga, LSL yang tidak mengetahui status HIV diri sendiri, tidak mendapatkan pelayanan pencegahan dan penularan HIV, dan tidak mengakses internet mengenai pencegahan dan penularan HIV berisiko lebih tinggi untuk berperilaku tidak konsisten dalam menggunakan kondom setiap kali melakukan hubungan seks. Maka dari itu, perlu programprogram yang berfungsi untuk meningkatkan pengetahuan LSL tentang status HIV dirinya sendiri, dan informasi mengenai pencegahan penularan HIV baik melalui program pelayanan maupun internet untuk meningkatkan konsistensi penggunaan kondom pada LSL non-pekerja seks.

Kata kunci: Konsistensi penggunaan kondom, MSM, HIV, Kebiasaan seksual

\section{Pendahuluan}

HIV saat ini menjadi permasalahan kesehatan utama dunia maupun Indonesia. Jumlah kasus baru HIV di Indonesia cenderung terus mengalami peningkatan setiap tahunnya sejak tahun 2005 hingga 2017 yaitu 859 kasus menjadi 48.300 kasus. ${ }^{1}$ Persentase penderita HIV yang mengetahui status HIVnya diestimasikan masih hanya $42 \%$ [36\%-49\%]. ${ }^{2}$ Nilai tersebut masih sangat jauh dari target 90-90-90 to End HIV Epidemic dimana salah satu targetnya yaitu persentase penderita

\section{A B S T R A C T}

HIV new cases in Indonesia tend to increase. Meanwhile, the global trend has decreased. Men who have sex with men (MSM) is one high-risk group of HIV. Efforts to prevent HIV transmission closely related to sexual behavior. This study used 1,161 samples of Integrated Biological and Behavioral Survey (IBBS) 2015 in the MSM group who are non-sexual worker. This cross sectional study aims to analyze determinants of the sexual behavior consistency of condom use by analysis up to bivariate using chisquare and prevalence ratio. Data is obtained by the respondent driven sampling (RDS) method, then excludes MSM sex workers. The results showed that the related factors with consistency of condom use are knowledge of HIV status with prevalence ratio (PR) 1.14 (95\% CI 1.02- 1.28), HIV prevention and transmission services with PR 1.18 (95\% CI 1.06-1.33), and access to the internet about HIV prevention and transmission with PR 1.16 (95\% CI 1.02-1.31). Thus, MSM who don't know their own HIV status, do not get HIV prevention and transmission services, and do not access the internet about HIV prevention and transmission have a higher risk of behaving use condom inconsistently when doing sex. Therefore, some programs need to increase MSM know their own HIV status, and improve information on preventing HIV transmission through both service programs and the internet to improve the consistency of condom use in MSM non-sexual workers.

Key words: Consistency of condom use, MSM, HIV, Sexual risk behaviour
HIV yang mengetahui statusnya seharusnya sudah mencapai $90 \% .^{2}$ Selain itu, pola kasus di Indonesia ini berbeda dengan pola di dunia yang mana jumlah kasus baru HIV di dunia sudah cenderung mengalami penurunan dari tahun 2000 ke tahun 2017 yaitu 2,8 juta menjadi 1,8 juta kasus baru. ${ }^{3}$

Perkembangan kasus HIV pada Laki-laki Seks dengan Laki-laki (LSL) di dunia terutama di Indonesia

*Korespondensi: Arum Zulaikhah, BPJS Kesehatan KC Kebumen, Jalan. Sarbini No. 100 Bumirejo Kec. Kebumen, Indonesia Email: arumzul@gmail.com 
perlu mendapat perhatian khusus dikarenakan perkembangannya yang semakin besar dari tahun ke tahun. ${ }^{1}$ LSL ini ialah laki-laki yang berhubungan seksual dengan laki-laki lainnya, terlepas dari memandang orientasi seksualnya, dan juga apakah ia juga berhubungan seksual dengan perempuan. ${ }^{4}$ Gay dan biseksual merupakan populasi yang paling sering terkena HIV di Amerika pada tahun 2016 dengan persentase kasus baru $67 \%$ atau 26.844 kasus baru dari 40.324 total kasus baru HIV. ${ }^{5}$ Jumlah kasus baru HIV pada LSL di Indonesia dari tahun ke tahun terus meningkat hingga menjadi kelompok risiko terbanyak pada tahun 2017 dan 2018 setelah kelompok risiko yang tidak diketahui. ${ }^{1}$

Salah satu upaya pencegahan penularan HIV ialah dengan penggunaan kondom yang benar setiap kali berhubungan seks. ${ }^{6}$ Tentunya upaya ini merupakan upaya pencegahan utama setelah upaya pencegahan tidak melakukan hubungan seks (abstinence). ${ }^{7}$ Namun, perilaku abstinence ini sulit diterapkan bagi yang aktif melakukan seks. ${ }^{7}$ Maka dari itu perilaku penggunaan kondom ini menjadi upaya pencegahan utama dalam mencegah HIV dan PIMS lainnya pada kelompok yang aktif melakukan seks.

Kelompok LSL memiliki risiko tinggi akibat perilaku seks yang dilakukannya yaitu dengan teknik seks anal yang berisiko menularkan HIV lebih tinggi dibandingkan dengan seks vaginal. ${ }^{8}$ Berdasarkan data STBP 2015, terdapat kelompok LSL yang bekerja sebagai pekerja seks dan selain pekerja seks. ${ }^{9}$ Aktifitas seks pada pekerja seks tentunya memiliki pola yang berbeda dengan LSL non pekerja seks, maka dari itu sebagai pengontrol pola perilaku, penelitian ini hanya dilakukan pada kelompok non pekerja seks.

Maka dari itu sebagai salah satu upaya pencegahan penularan utama HIV pada orang yang aktif secara seksual, kondisi penggunaan kondom secara konsisten perlu diketahui beserta faktor-faktor yang mempengaruhinya terutama pada pada kelompok risiko tinggi LSL. Penelitian ini bertujuan untuk mengetahui besar dan kekuatan hubungan faktorfaktor yang mempengaruhi konsistensi penggunaan kondom pada kelompok LSL non pekerja seks berdasarkan hasil STBP 2015. Hasil yang diharapkan dapat berguna sebagai bahan evidence based untuk melakukan upaya pencegahan penularan HIV-AIDS melalui strategi peningkatan penggunaan kondom secara konsisten pada LSL non pekerja seks.

\section{Metode}

Penelitian ini menggunakan data sekunder hasil Survei Terpadu Biologis dan Perilaku (STBP) tahun 2015 dengan desain studi cross sectional. Variabel independen penelitian ini adalah pengetahuan tentang pencegahan dan penularan HIV, pengetahuan status HIV diri sendiri, umur, status bekerja, pendidikan, pelayanan pencegahan dan penularan HIV, serta akses internet mengenai pencegahan dan penularan HIV. Pengetahuan tentang pencegahan dan penularan HIV ini merupakan pertanyaan kognitif yang menjadi indicator pengetahuan esensial dalam domain pengetahuan penularan HIV oleh UNAIDS yang terdiri dari 5 pertanyaan dasar dan dengan batas pengetahuan baik jika responden menjawab benar diatas 2 pertanyaan. Pengetahuan status HIV diri sendiri ialah jika LSL pernah melakukan tes dan mengetahui hasil tes status HIV-nya. Umur menggunakan pengelompokan youth: 15-24 tahun, dan adult: $>24$ tahun. Status bekerja ditunjukkan dengan apakah responden bekerja atau tidak. Pendidikan yang dimaksud adalah pendidikan formal yang pernah ditempuh responden dengan dibagi menjadi dua kategori pendidikan dasar (tidak sekolah-tamat SMP), dan pendidikan menengah ke atas (tidak tamat SMAperguruan tinggi). Pelayanan pencegahan dan penularan HIV yaitu keikutsertaan responden dalam mengikuti diskusi atau pertemuan dengan pendamping lapangan (PL) HIV. Akses internet mengenai pencegahan dan penularan HIV yang dimaksud yaitu pernah atau tidak >=1 kali responden mengakses intenet dalam rangka mendapat informasi tentang pencegahan penularan HIV-AIDS selama 3 bulan terakhir. Variabel dependennya adalah konsistensi penggunaan kondom. Konsistensi penggunaan kondom pada LSL yang dimaksud adalah apakah LSL selalu menggunakan kondom setiap kali berhubungan seks baik dengan laki-laki maupun perempuan selama sebulan terakhir.

Penelitian dilakukan pada 6 daerah di Indonesia yaitu DKI Jakarta, Kota Bandung, Kabupaten dan Kota Semarang, Kota Surabaya, Kabupaten dan Kota Malang, dan Kota Denpasar dengan menggunakan data STBP 2015 pada kelompok LSL yang dianalisis pada Mei-Juli 2019. Pengumpulan STBP 2015 pada kelompok LSL ini dengan menggunakan metode pengumpulan data Respondent driven sampling (RDS). RDS ini adalah sebuah teknik sampling secara jemput bola (snowball) berdasarkan pada kuota perekrutan untuk yang menghindari perekrutan keseluruhan sampel dari sejumlah individu yang terbatas. RDS berawal dari sejumlah kecil peserta yang dipilih secara purposif yang biasanya disebut seed, kemudian dipilih seheterogen mungkin. Kemudian, satu seed merekrut hingga mencapai paling tidak 3 gelombang perekrutan. Jumlah responden STBP pada LSL 2015 didapatkan sebanyak 1.496 responden.

Alur pengambilan sampel pada penelitian ini dengan memilih sampel yang memenuhi kriteria inklusi dan eksklusi penelitian ini, Kriteria inklusi penelitian 
ini sama dengan kriteria inklusi STBP 2015 pada kelompok LSL yaitu laki-laki berumur 15 tahun atau lebih, telah tinggal di lokasi penelitian paling tidak selama satu bulan, dan telah berhubungan seks dengan seorang laki-laki dalam setahun terakhir. Dengan kriteria tersebut sehingga didapatkan 1.495 responden. Responden yang di eksklusi adalah responden yang bekerja sebagai pekerja seks, dan tidak lengkap atau menjawab "tidak ingat" dalam menjawab pertanyaan pada variabel yang diteliti kecuali pada pertanyaan pengetahuan tentang pencegahan dan penularan HIV. Berdasarkan kriteria eksklusi ini kemudian di dapatkan responden sebesar 1.161 responden. Analisis yang di lakukan adalah analisis univariat dengan persentase, dan analisis bivariat menggunakan uji chi-square untuk mengetahui hubungannya dan prevalence ratio untuk mengetahui kekuatan hubungan variabel independen dan dependennya.

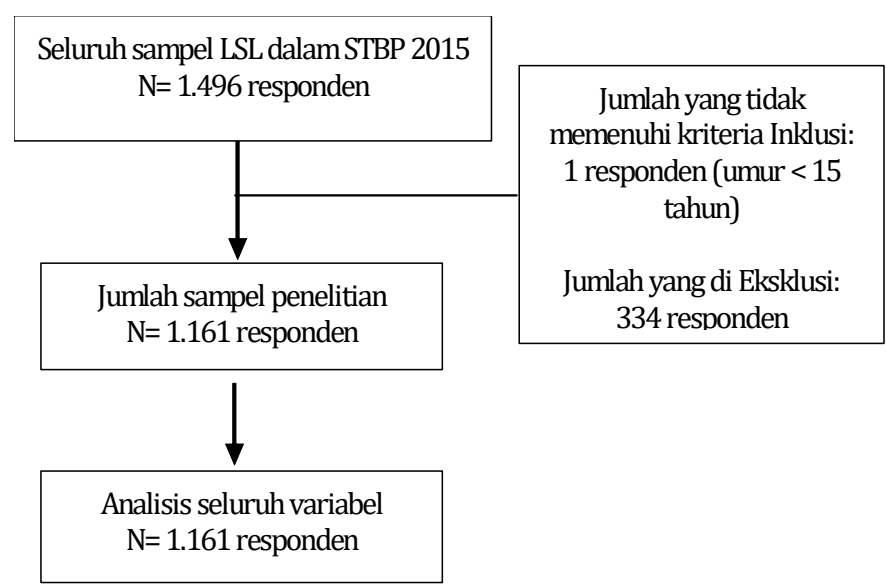

Gambar 1. Alur Pengambilan Sampel

Penelitian ini telah lulus etik dari Komisi Etik Riset dan Pengabdian Kesehatan Masyarakat Fakultas Kesehatan Masyarakat Universitas Indonesia dengan Nomor: Ket-488/UN2.F10/PPM.00.02/2019 tanggal 28 Mei 2019.

\section{Hasil}

Pada Tabel 1, LSL non-pekerja seks yang bertempat tinggal di 6 daerah Indonesia dalam STBP 2015 yang tidak konsisten dalam menggunakan kondom sebesar 50,1\% (582 responden). LSL non pekerja seks yang memiliki pengetahuan baik tentang pencegahan dan penularan HIV-AIDS mencapai 84,2\%. Sebagian besar LSL tidak mengetahui status HIV dirinya sendiri yaitu sebesar 64,2\%. LSL tersebut lebih banyak berusia diatas 24 tahun, bekerja, dan berpendidikan menengah ke atas. Sebanyak 57,7\% LSL sudah menerima layanan pencegahan dan penularan HIV secara langsung. Namun masih sedikit yang mengakses informasi mengenai pencegahan dan penularan HIV menggunakan internet yaitu sebesar 37,5\%.
Tabel 2. Karakteristik LSL non pekerja seks peserta STBP 2015 pada LSL di Indonesia ( $n=1.161)$

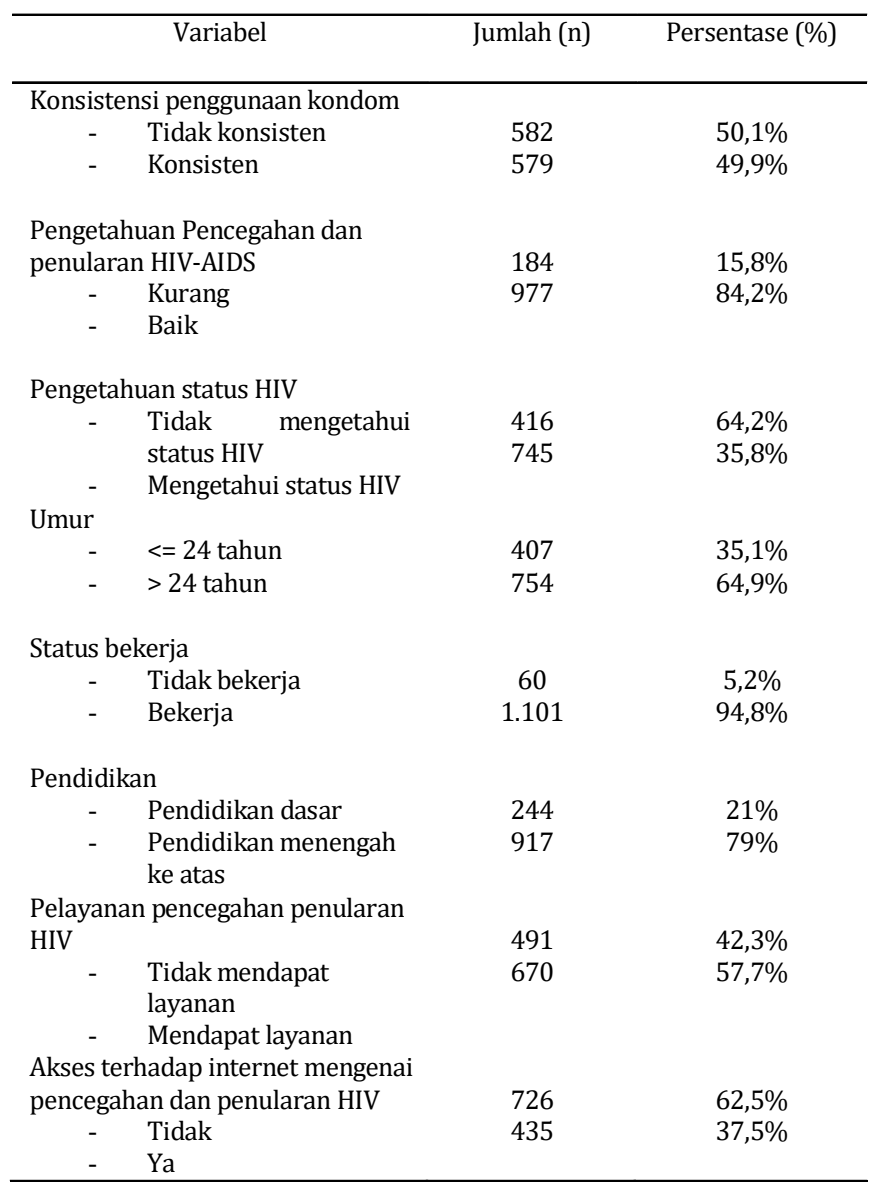

Tabel.2 penelitian ini menunjukkan bahwa ternyata tidak ada hubungan yang signifikan antara pengetahuan tentang pencegahan dan penularan HIV dengan penggunaan kondom yang tidak konsisten dengan hasil uji chi-square ( $\mathrm{p}$-value $=0,545,95 \% \mathrm{CI}$ ) dan PR sebesar 1,04 (CI 95\% 0,090-1,22). Begitu pula dengan umur, status bekerja, pendidikan LSL yang tidak memiliki hubungan yang signifikan dengan konsistensi penggunaan kondom pada LSL non pekerja seks. Namun, untuk pengetahuan mengenai status HIV diri sendiri berhubungan signifikan dengan perilaku konsistensi penggunaan kondom. Hubungan yang ada menunjukkan bahwa kelompok LSL yang tidak mengetahui status HIV dirinya sendiri memiliki risiko lebih tinggi untuk berperilaku menggunakan kondom secara tidak konsisten 1,14 kali dibanding kelompok LSL yang mengetahui status HIV dirinya sendiri PR 1,14 (95\% CI 1,02-1,28). Hubungan variabel lain yang bermakna signifikan dengan perilaku konsistensi penggunaan kondom adalah variabel pelayanan pencegahan dan penularan HIV-AIDS dan akses internet tentang pencegahan dan penularan HIV-AIDS. LSL yang tidak mendapatkan layanan pencegahan dan penularan HIV-AIDS berisiko untuk berperilaku menggunakan kondom secara tidak konsisten 1,18 kali dibanding kelompok LSL yang mendapatkan layanan pencegahan 
Tabel 2. Faktor-Faktor yang Berhubungan dengan Penggunaan Kondom yang Tidak Konsisten pada LSL Non Pekerja Seks Peserta STBP 2015 pada LSL di Indonesia $(n=1.161)$

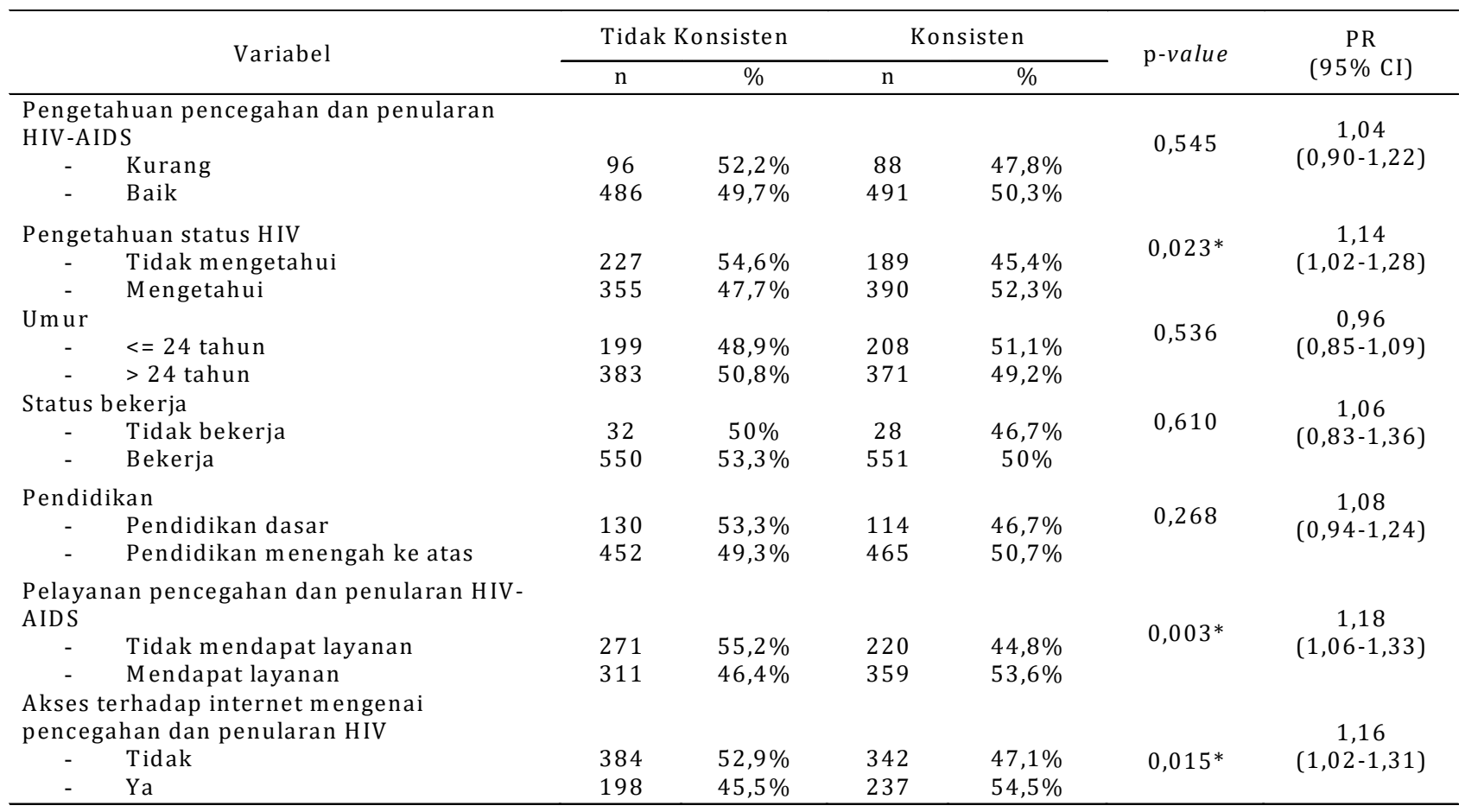

*Hasil uji statistik signifikan (pd" 0,05)

dan penularan HIV-AIDS PR 1,18 (95\% CI 1,06-1,33,). Sedangkan hubungannya dengan variabel akses terhadap internet tentang pencegahan dan penularan HIV-AIDS bermakna bahwa LSL yang tidak mengakses internet tentang pencegahan dan penularan HIV memiliki risiko untuk menggunakan kondom secara tidak konsisten 1,16 kali dibanding kelompok LSL yang yang mengakses internet tentang pencegahan dan penularan HIV-AIDS PR 1,16 (95\% CI 1,02-1,31).

\section{Pembahasan}

Keterbatasan pada penelitian ini adalah pertama karena data yang digunakan adalah data sekunder sehingga variabel yang diteliti terbatas pada yang ada pada STBP 2015. Kedua, desain studi yang digunakan crossectional membuat hubungan yang ada ditunjukkan dua arah, tidak bisa menunjukkan sebab akibat yang satu arah. Dengan desain studi tersebut juga membatasi jumlah kategori variabelnya dua jenis sehingga hasil hubungan kurang ketat. Adanya keterbatasan penelitian ini diharapkan penelitian lain yang menghasilkan penelitian yang lebih baik lagi.

Hasil penelitian LSL yang menggunakan kondom secara tidak konsisten saat berhubungan seks baik dengan laki-laki maupun perempuan pada penelitian ini masih rendah sejalan dengan penelitian Fransiska, dan Gusmiati pada 2017 bahwa konsistensi penggunaan kondom pada komunitas homoseksual di Indonesia menunjukkan besar LSL yang tidak konsisten menggunakan kondom sebesar $73,7 \%{ }^{10}$
Hal ini menunjukkan bahwa masih rendahnya penggunaan kondom secara konsisten setiap kali berhubungan seks baik penetrasi anal maupun vaginal pada kalangan LSL.

Pengetahuan LSL non pekerja seks mengenai pencegahan dan penularan HIV-AIDS berdasarkan 5 pertanyaan yang dijadikan standar global oleh UNAIDS dalam United Nations General Assembly Special Session on HIV/AIDS (UNGASS) sudah cukup baik yaitu berpengetahuan baik sudah mencapai $84,2 \%$. Namun, persentase ini masih dibawah target dari UNAIDS pada tahun 2010 yaitu sebesar 95\% yang memiliki pengetahuan baik. ${ }^{11}$

Pengetahuan LSL non pekerja seks mengenai status HIV dirinya sendiri pada penelitian ini masih rendah sejalan dengan data UNAIDS 2017 yang menyatakan bahwa penderita HIV semua kelompok di Indonesia yang mengetahui status HIVnya diestimasikan baru mencapai $42 \%$. Nilai ini masih sangat jauh dengan pola perkembangan yang lambat untuk mencapai target percepatan 90-90-90 testing and treatment pada tahun $2020 .^{12}$ Sebagai kelompok berisiko, LSL penting mengetahui status HIV nya.

LSL pada penelitian ini memiliki karakter umur diatas 24 tahun persentasenya lebih besar dibandingkan dengan yang berumur kurang dari atau sama dengan 24 tahun yaitu sebesar 64,9\%. Hal ini sama dengan kondisi pada populasi LSL keseluruhan STBP 2015 dimana yang berumur diatas 24 tahun juga lebih besar dari yang berumur kurang dari sama dengan 24 tahun kecuali pada LSL di kota Malang. ${ }^{9}$ Selain itu, LSL 
yang tidak bekerja sebagai pekerja seks sebagian besar tetap produktif bekerja yaitu sebesar 94,8\%. Para LSL yang ada memiliki tingkatan pendidikan menengah keatas dengan besar 79\%.

Pada penelitian ini LSL non pekerja seks yang mendapatkan pelayanan pencegahan penularan HIVAIDS dari petugas PL baru mencapai 57,7\% dan sisanya masih belum mendapatkan pelayanan pencegahan dan penularan HIV-AIDS khusus bagi kelompok berisiko tinggi LSL. Akses terhadap pelayanan pencegahan sebagai tugas dari PL berperan penting dalam pencegahan penularan HIV karena tujuan adanya PL ini adalah untuk mengintervensi perubahan perilaku kepada kelompok dampingan (KD) termasuk LSL. ${ }^{13}$

Untuk akses internet mengenai pencegahan dan penularan HIV-AIDS pada LSL sebagian besar belum pernah mengakses informasi mengenai pencegahan dan penularan HIV-AIDS melalui internet. LSL yang telah mengakses baru mencapai 37,5\%. Akses terhadap internet mengenai pencegahan dan penularan HIV-AIDS ini tentunya masih kecil melihat tren penggunaan internet di kalangan masyarakat sebagai media komunikasi dan informasi yang sedang ramai digunakan masyarakat berumur 13-18 tahun sebesar $75,5 \%$, pada umur $19-34$ tahun sebesar $74,23 \%$ dan umur 35-54 sebesar 44,06\%. ${ }^{14}$ Sehingga, perlu pembuatan media informasi internet tentang pencegahan dan penularan HIV-AIDS yang menarik untuk meningkatkan minat kelompok sasaran mendapatkan informasi tentang pencegahan dan penularan HIV-AIDS yang tepat.

Perilaku penggunaan kondom secara konsisten yang menjadi perilaku pencegahan utama bagi yang aktif melakukan kegiatan seksual pada LSL masih menunjukan angka yang masih rendah yaitu 50,1\%. Padahal berbagai upaya program dan penelitian telah dilakukan dalam upaya pencegahan HIV. Dalam rangka meng-update perkembangan kondisi perilaku pencegahan HIV ini peneliti menganalisis faktor-faktor yang berhubungan dengan perilaku konsistensi penggunaan kondom. Untuk mengetahui faktor-faktor yang mempengaruhi perilaku tersebut pada penelitian ini menggunakan pendekatan teori precede-proceed yaitu teori pembentukan perilaku dipengaruhi oleh faktor predisposing, enabling, dan reinforcing. ${ }^{15}$ Faktor predisposing yang dianalisis pada penelitian ini adalah pengetahuan, umur, pendidikan, dan status bekerja. Faktor enabling yang dianalisis adalah akses ke pelayanan pencegahan penularan HIV-AIDS, dan akses terhadap media dan informasi melalui internet.

Pengetahuan sebagai faktor predisposingyang mempengaruhi perilaku manusia dalam bertindak seharusnya membuat pengetahuan tentang pencegahan dan penularan HIV-AIDS dengan perilaku konsistensi penggunaan kondom berhubungan. Namun, hasil penelitian menunjukkan tidak ada hubungan dengan PR sebesar 1,04 (95\% CI 0,90-1,22). Nilai ini bermakna bahwa tidak ada hubungan yang signifikan, melainkan hanya hubungan parsial antara kelompok LSL yang memiliki pengetahuan kurang tentang pencegahan dan penularan HIV dengan konsistensi penggunaan kondom. Studi lain menunjukkan hasil yang sejalan dengan penelitian ini yaitu pengetahuan tidak mempengaruhi tindakan pencegahan HIV dan AIDS pada komunitas LSL. ${ }^{16} \mathrm{Hal}$ yang sama terjadi pada penelitian pada LSL di Kamboja yang menunjukan bahwa pengetahuan tentang HIV sudah bagus namun tidak ada hubungan yang signifikan dengan kelompok yang konsisten dan tidak konsisten menggunakan kondom. ${ }^{17} \mathrm{Hal}$ ini bukan berarti bahwa pengetahuan tentang pencegahan dan penularan HIV tidak penting. Namun, pada kelompok LSL ini memerlukan pengetahuan tentang pencegahan dan penularan HIV yang spesifik berkaitan dengan perilaku berisiko pada pasangan LSL. ${ }^{18}$ Sedangkan pada penelitian ini indikator yang digunakan adalah dengan 5 pertanyaan dasar esensial yang tidak spesifik mengenai pencegahan dan penularan HIV pada LSL. Dengan begitu untuk mengetahui pengetahuan LSL ini diperlukan penelitian mengenai spesifik pengetahuan pencegahan dan penularan untuk LSL.

Program internasional sedang gencar mengenai pentingnya untuk pengetahuan status HIV diri sendiri. Adanya target 90-90-90 testing and treatment menjadi salah satu bukti pentingnya pengetahuan status diri terhadap upaya pencegahan penularan HIV dengan salah satu targetnya yaitu $90 \%$ penderita HIV mengetahui status HIVnya. ${ }^{12}$ Pada penelitian ini hubungan pengetahuan tentang status HIV diri sendiri dengan konsistensi penggunaan kondom saat berhubungan seks ditunjukkan dengan nilai PR sebesar 1,14 (95\% CI: 1,02-1,28). Hubungan tersebut bermakna secara signifikan bahwa LSL yang tidak mengetahui status HIVnya memiliki risiko untuk menggunakan kondom secara tidak konsisten ketika berhubungan seks 1,14 kali dibandingkan LSL yang mengetahui status HIV-nya. Penelitian ini sejalan dengan penelitian sebelumnya yang menganalisis hubungan tahu status HIV dengan konsistensi penggunaan kondom pada hasil STBP 2013 di Yogyakarta yang menunjukkan OR crude sebesar 3,7 (CI 95\% 1,4-10,1) (pvalue $=0,009,95 \% \mathrm{CI}) .{ }^{19}$ Mengetahui status HIV merupakan hal yang sangat penting dalam membuat keputusan perilaku mereka. Hal ini juga sudah menjadi program UNAIDS yaitu 90-90-90 testing and treatment karena pentingnya dampak dari pencapaian program tersebut dalam mencegah penularan HIV. Pengetahuan status HIV ini penting bagi LSL untuk menentukan arah 
pencegahan dan penularan HIV-AIDS yang tepat. Mereka yang mengetahui status HIV negatif, akan mendorong mereka untuk berperilaku yang dapat mencegah perubahan menjadi HIV positif dikemudian hari. Sedangkan mereka yang mengetahui hasilnya positif, bukan hal yang mudah diterima, namun akan membuat mereka berperilaku hidup sehat agar memperpanjang hidup mereka dan tidak menularkan ke orang lain. ${ }^{12}$ Maka dari itu, dengan adanya hubungan yang signifikan antara pengetahuan tentang status HIV dengan konsistensi penggunaan kondom diharapkan adanya penguatan program untuk meningkatkan kemauan LSL untuk mengetahui status HIV-nya.

Umur adalah indikator lamanya hidup. Semakin bertambah umur semakin banyak informasi yang di dapatkan sehingga semakin matang seseorang dalam berperilaku. Namun, selain umur kematangan berperilaku juga dipengaruhi oleh faktor eksternal lingkungan. Pada hubungan umur dengan perilaku konsistensi penggunaan kondom kali ini tidak bermakna secara signifikan dengan nilai PR sebesar 0,96 (95\% CI 0,85-1,09). Umur hanya berhubungan secara parsial dengan perilaku konsisten penggunaan kondom. Pada penelitian sebelumnya juga menunjukkan bahwa tidak ada hubungan yang signifikan antara umur dan penggunaan kondom konsisten dengan nilai PR sebesar 1,15 dan CI 0,921,45 (p-value $=0,358,95 \% \mathrm{CI}$ ). ${ }^{20}$ Berbeda dengan penelitian di Kamboja yang menunjukkan bahwa ada hubungan yang signifikan bahwa LSL yang berumur 25 tahun atau lebih berisiko 1,77 kali memiliki perilaku tidak konsisten menggunakan kondom dibanding yang berumur 24 tahun atau kurang dengan AOR 1,77 (95\% CI 1,09-2,86). Pada penelitian tersebut dapat terjadi akibat intervensi yang dilakukan lebih difokuskan pada umur muda. ${ }^{17}$ Begitu pula pada penelitian di Ghana yang menunjukkan yang berumur dibawah 25 tahun lebih berisiko berperilaku beresiko dibanding yang berumur 25 tahun atau lebih. ${ }^{21}$ Umur sebagai indikator lamanya hidup dan mempengaruhi kedewasaan berpikir dan bertindak tidak membuat LSL mempunyai perilaku yang lebih baik yaitu konsisten dalam menggunakaan kondom.

Hubungan dengan status bekerja tanpa adanya pekerja seks menunjukkan hasil yang tidak signifikan berhubungan, dengan nilai PR sebesar 1,06 (CI 95\% 0,83-1,36) (p-value=0,610 95\% CI). Hasil ini sejalan dengan penelitian pada LSL di Kamboja yang menunjukan tidak ada hubungan signifikan antara status bekerja dengan konsistensi penggunaan kondom (p-value $=0,38$ 95\% CI ). ${ }^{17}$ Baik LSL bekerja maupun tidak bekerja tidak mempengaruhi pola perilaku penggunaan kondom mereka.
Hubungan dengan faktor pendidikan pada penelitian ini tidak berhubungan signifikan dengan nilai PR sebesar 1,08 (CI 95\% 0,94-1,24) (p-value=0,268 $95 \% \mathrm{CI}$ ). Sejalan dengan penelitian sebelumnya yang menujukan bahwa tidak ada hubungan yang signifikan antara tingkat pendidikan dengan perilaku penggunaan kondom konisten dengan nilai PR sebesar 1,142 dan CI 0,93-1,4 (p-value $=0,3$ 95\% CI). ${ }^{20}$ Sejalan pula dengan penelitian pada LSL di Kamboja yag menunjukan tidak ada hubungan yang signifikan pendidikan dengan perilaku konsistensi penggunaan kondom ( $p$-value $=$ 0,67 95\% CI). ${ }^{17}$ Adanya tingkat pendidikan tidak mempengaruhi mereka untuk berperilaku konsisten menggunakan kondom. Mereka tetap memiliki perilaku yang tidak berbeda meskipun telah menempuh pendidikan yang lebih tinggi.

Hubungan dengan pelayanan pencegahan dan penularan HIV-AIDS menunjukkan hubungan yang signifikan dengan nilai PR 1,19 dan CI 1,06-1,33 (pvalue $=0,003,95 \% \mathrm{CI}$ ) yang bermakna bahwa LSL yang tidak mendapatkan layanan pencegahan dan penularan HIV-AIDS memiliki risiko untuk berperilaku tidak konsisten dalam menggunakan kondom saat berhubungan seks 1,18 kali dibandingkan dengan LSL yang mendapatkan layanan pencegahan dan penularan HIV-AIDS. Hal ini sejalan dengan penelitian sebelumnya yang menunjukkan bahwa LSL yang mengikuti program HIV/AIDS dengan kategori kurang memiliki risiko untuk berperilaku tidak konsisten menggunakan kondom 1,323 kali dibandingkan yang mengikuti program HIV/AIDS dengan baik dengan CI 1,08-1,62 (p-value $=0,005,95 \% \mathrm{CI}$ ). ${ }^{20} \mathrm{Hal}$ ini menunjukkan adanya keefektifan program pelayanan pencegahan dan penularan HIV untuk membuat LSL berperilaku menggunakan kondom secara konsisten sehingga perlu penguatan dan perluasan program penjangkauan LSL oleh PL ini dikarenakan persentase akses ke pelayanan pencegahan dan penularan ini yang masih sebesar $57,7 \%$.

Hubungan faktor akses terhadap internet mengenai pencegahan dan penularan HIV-AIDS berhubungan signifikan dengan nilai PR sebesar 1,16 (CI 95\% 1,06-1,33) (p-value=0,015, 95\% CI) yang bermakna signifikan bahwa LSL yang tidak mengakses internet tentang pencegahan dan penularan HIV berisiko untuk berperilaku menggunakan kondom secara tidak konsisten 1,16 kali dibanding yang mengakses internet tentang pencegahan dan penularan HIV. Internet sebagai salah media sumber informasi sejalan dengan hasil penelitian terdahulu dimana sumber media informasi berhubungan signifikan dengan perilaku penggunaan kondom konsisten pada LSL. Pada penelitian tersebut bermakna bahwa pada 
kelompok yang kurang dalam mengakses sumber informasi HIV/AIDS berisiko menggunakan kondom tidak selalu konsisten 1,401 kali dibanding yang mengakses sumber informasi dengan baik dengan nilai PR sebesar 1,401 dan CI 1,17-1,68 (p-value=0,001, $95 \%$ CI) (20). Media internet merupakan media yang cukup mudah diakses sehingga perlu adanya pemanfaatan media informasi internet ini untuk memberikan informasi mengenai pencegahan dan penularan HIV-AIDS dengan tepat dan bermanfaat.

\section{Kesimpulan}

HIV sebagai salah satu permasalahan utama di Indonesia saat ini masih memiliki perkembangan cukup tinggi di Indonesia. Dibandingkan dengan perkembangan kondisi HIV di dunia menjadikan kita perlu mengetahui strategi apa yang perlu dilakukan di Indonesia. Penggunaan kondom secara konsisten merupakan salah satu pencegahan utama dalam upaya pencegahan dan penularan HIV untuk mereka yang aktif beraktivitas seks. Sehingga, pada penelitian ini bertujuan untuk mengetahui determinan perilaku konsistensi penggunaan kondom. Determinan ini dapat digunakan untuk dasar membuat strategi peningkatan upaya pencegahan dan penularan HIV melalui konsistensi penggunaan kondom.

Determinan perilaku konsistensi penggunaan kondom pada penelitian kali adalah adalah pengetahuan status HIV diri sendiri dengan PR sebesar 1,14 (95\% CI 1,02-1,28), akses ke pelayanan pencegahan dan penularan HIV-AIDS dengan PR sebesar 1,18 (95\% CI 1,06-1,33), dan akses terhadap media informasi internet tentang pencegahan dan penularan HIV-AIDS dengan PR sebesar 1,16 (95\% CI, 1,02-1,31).

\section{Acknowledgement}

Data yang digunakan pada penelitian ini adalah data Survei Terpadu Biologi dan Perilaku (STBP) 2015 pada kelompok LSL. Penulis berterimakasih pada pimpinan dan staf Subdit HIV dan PIMS Kementerian Kesehatan Republik Indonesia yang telah membantu penelitian ini.

\section{Daftar Pustaka}

1. Kemenkes RI. Laporan Situasi Perkembangan HIV-AIDS \& PIMS di Indonesia Januari-Desember 2017. 2018.

2. UNAIDS. UNAIDS [Internet]. 2017 [cited 2019 Mar 3]. Available from: www.unaids.org/en/regionscountries/ countries/indonesia

3. WHO. HIV/AIDS: Data and Statistics [Internet]. 2019. Available from: https://www.who.int/hiv/data/en/
4. Kemenkes RI. Pedoman Nasional Penanganan Infeksi Menular Seksual 2015. Jakarta: Kementerian Kesehatan RI; 2015.

5. CDC. HIV and Gay and Bisexual Men [Internet]. 2018 [cited 2019 Feb 27]. Available from: https://www.cdc.gov/hiv/ group/msm/index.html

6. CDC. What are the best ways to decrease my chances of getting or transmitting HIV? [Internet]. [cited 2019 Oct 14]. Available from: https://wwwn.cdc.gov/hivrisk/ best_actions/

7. CDC. What can decrease HIV risk? [Internet]. [cited 2019 Oct 14]. Available from: https://wwwn.cdc.gov/hivrisk/ decreased_risk/

8. CDC. HIV/AIDS: HIV Transmission [Internet]. 2018 [cited 2019 Feb 26]. Available from: https://www.cdc.gov/hiv/ basics/transmission.html.

9. Kemenkes RI. Laporan STBP 2015. 2016.

10. Aids HI V. Fransiska, Gusmiati | Jumlah Pasangan | 474. 2017;474-9.

11. UNAIDS. Monitoring the Declaration of Commitment on HIV/AIDS/ : Guidelines on Construction of Core Indicators. Vol. 52 Suppl 2, Joint United Nations Programme on HIV and AIDS. 2002. S77-86 p.

12. UNAIDS. UNAIDS - Knowledge is Power. Jt United Nations Program HIV/AIDS [Internet]. 2018; Available from: http:// www.unaids.org/sites/default/files/media_asset/ jc2940_knowledge-is-power-report_en.pdf

13. Kemenkes RI. Kebijakan Dalam Penanggulangan IMS, HIV dan AIDS. Jakarta; 2009. (1).

14. Asosiasi Penyelenggara Jasa Internet Indonesia. Infografis Penetrasi dan Perilaku Pengguna Internet Indonesia 2017 [Internet]. 2017. Available from: https:// www.kominfo.go.id/content/detail/4286/penggunainternet-indonesia-nomor-enam-dunia/0/sorotan_media

15. Notoatmodjo S. Promosi Kesehatan dan Perilaku Kesehatan. Jakarta; 2014.

16. Rokhmah D, Khoiron. Urgensi Perubahan Implementasi Kebijakan dalam Menurunkan IMS, HIV dan Aids pada Komunitas LSL di Kabupaten Jember. Media Kesehat Masy Indones. 2015;11(4):210-7.

17. Yi S, Tuot S, Chhoun P, Pal K, Tith K, Brody C. Factors associated with inconsistent condom use among men who have sex with men in Cambodia. PLoS One. 2015;10(8):115.

18. Baral SD, Ketende S, Mnisi Z, Mabuza X, Grosso A, Sithole $B$, et al. A cross-sectional assessment of the burden of HIV and associated individual- and structural-level characteristics among men who have sex with men in Swaziland. J Int AIDS Soc. 2013;16 Suppl 3(Suppl 3):1-11.

19. Anggraeni RF. Pengaruh Tahu Status HIV terhadap Penggunaan Kondom Konsisten pada Laki-Laki yang Seks dengan Lelaki di Yogyakarta dan Makassar (Analisis Data Survei Terpadau Biologis dan Perilaku Tahun 2013). Universitas Indonesia; 2015.

20. Sidabutar NHT. Faktor-faktor yang Mempengaruhi Penggunaan Kondom Secara Konsisten Sebagai Upaya Pencegahan HIV/AIDS pada Lelaki Seks Lelaki (LSL) di Tangerang, Yogyakarta, dan Makassar Tahun 2013 "Analisis Lanjut Survei Terpadau Biologis dan Perilaku (STBP) 2013." Universitas Indonesia; 2018. 
21. Nelson LE, Wilton L, Agyarko-Poku T, Zhang N, Aluoch M, Thach CT, etal. The association of HIV stigma and HIV/STD knowledge with sexual risk behaviors among adolescent and adult men who have sex with men in Ghana, West Africa. Res Nurs Health. 2015; 38(3): 194-206. 